\title{
Gordon White
}

The rise to power of the economic reformers in China is not an isolated political event, but one which has parallels in other state socialist societies in both East and South. It is the thesis of this article that the reform phenomenon is a characteristic (and probably ineluctable) stage of a particular pattern of socialist development which one might call the classic Leninist trajectory. This traditional mode of socialist development began in the Soviet Union, was transferred to Eastern Europe and was later adopted by the first wave of revoluntary socialist regimes in the Third World, notably China, North Korea, Vietnam and Cuba. In each Third World case, a period of revolutionary struggle was followed by the assumption of power by a communist or workers' party which established a one-party political system and organised a fundamental transformation of the economy involving socialisation of industry and agriculture and the construction of a comprehensive framework of central planning. The state socialist political economy in each of these countries is of relatively long standing; though their experience is in many ways diverse, there are strikingly common elements (many of which they share with Eastern Europe) on which we can base some tentative judgements about their political and economic dynamics as a distinct developmental genre. It appears that they undergo certain characteristic transitions which reflect the influence of changes in historical conditions, society and the state, and of certain basic problematic features of centrally planned economies and Leninist polities.

The key determinants of transition are three: (i) the current context - domestic and international, economic and political, technical and social, (ii) the evolving social structure, notably the emergence and consolidation of new class forces, (iii) the nature of the state as an agent of class formation and a matrix of political relations. At each stage, these factors shape (and are shaped by) the specific mix of institutional alternatives characteristic of state socialism - state action, markets and mass participation - and the specific policy agenda of the period.

Using this broad framework, one can distinguish three key phases and transitions in revolutionary socialist development: (i) revolutionary voluntarism and its limits: this initial phase involves the transition from a revolutionary era of politico-military struggle to the post-revolutionary stage of socialist construction. Its most vivid manifestations were Maoism in China and Guevaraism in Cuba. In the initial post-revolutionary period, the nascent state is dominated by radical elements representing the political aspirations of the revolutionary mass coalition; the social structure is in turmoil and transformation; and internal and external politico-economic conditions are threatening. Institutionally, state-building combines with mass mobilisation; markets are seen as power bases for enemy classes and are subjected to increasing controls. The policy agenda calls for rapid social and institutional transformation. In this context, the methodological heritage of the revolutionary period is appropriate; as conditions change, however, its applicability to the key problems of development is increasingly brought into question.

(ii) Bureaucratic voluntarism and its limits: To the extent that the strategic tasks of the immediate postrevolutionary period are achieved, the revolutionary model of social mobilisation is undermined. The burgeoning state apparatus is increasingly managed by people without revolutionary experience; a reorganised social structure is taking shape with institutionalised patterns of social mobility and a strategic role for educated, primarily urban, strata; as the state is consolidated, it manages to marginalise domestic counter-revolutionary opposition and to establish a modus vivendi with the external world. The strategic task of the era becomes rapid economic development, and the state takes on the central role in steering the economy through a network of increasingly complex bureaucratic organisations. In the terminology of Max Weber, the revolution is being 'institutionalised'; from the perspective of many former revolutionaries, 'revisionism', 'degeneration' or 'retrogression' are setting in. Thus the transition between stages is usually marked by political conflict and ideological disagreement among the Party leadership. The revolutionaries may maintain their influence for some considerable time: in Vietnam revolutionary methods were prolonged by the war; Chinese Maoist leaders stayed in power for several years after Mao's death; in north Korea former guerilla leader Kim Il Sung still clings to power, aided by the military confrontation with South Korea; and in Cuba Fidel Castro has attempted to use mass participation and popular power as a counterweight to the growth of bureaucracy. However, the new phase of 
bureaucratic voluntarism also creates the conditions for its own supercession.

(iii) Reformism and market socialism: In a transitional process much analysed in socialist countries and abroad, bureaucratic voluntarism becomes increasingly irrational economically and unacceptable politically. The new state apparatus has bred new professionals with specialised training, reared in a post-revoluntary environment, who develop interests which are increasingly incompatible with those of the politico-administration elite and further them by technocratic means. The population wearies of postponed consumption, and increased social differentiation leads to proliferating sectional interests and demands which beat on the doors of Party hegemony. The traditional methods of directive planning become more and more ineffective as the economic structure becomes more complex and social demands diversify. There are thus moves to change the institutional mix, with more scope for markets, greater political freedom and cultural diversity. The policy agenda privileges economic over political reform, concentrating on improving economic efficiency and productivity.

This three-stage transition is, of course, an ideal type, and sits uneasily with some cases. The uniformity of Kim Il Sung's rule in north Korea is an apparent counter-example, but one which has postponed rather than avoided these critical contradictions - when the dam breaks, the flood may be devastating. In Cuba, the tentative market reforms of the early 1980s have been reversed over the past year, but this reversal may intensify rather than resolve Cuba's economic difficulties. Moreover, the transition between stages is not clear-cut; each new stage retains important elements of the one preceding. The fit between changing socio-economic requirements and political demands on the one hand, and embedded sociopolitical institutions and attitudes on the other, is not a neat one.

China is a relatively 'pure' example of the classic Leninist trajectory. In this article, I intend to focus on the third transition, from a hybrid phase (1956-1976) which combined revolutionary and bureaucratic voluntarism, to the post-Mao phase of economic reformism and market socialism from 1977 to the present day. What were the political factors underlying this transition and what are its implications for China's political process in future?

\section{The Politics of China's Reform Process}

(i) Origins of the Reforms There are a number of explanations of the origins of the economic reforms in China after the death of Mao. Three types can be discerned: political explanations which, for example, stress political or ideological conflict within the CCP leadership and increasing mass disenchantment with the Party, or highlight the importance of different political 'generations' within the CCP elite; economic explanations which rest on a hypothesised transition from 'extensive' to 'intensive' growth, or emphasise the growing contradictions between an increasingly complex economy and a directive planning system; class analyses which trace the emergence of a new strata from within the state socialist political economy, for whom the project of economic reform is a means to a greater social power in opposition to the apparatchiki in party and government machines.

A full analysis would need to stitch them together into a coherent analytical tapestry. I do not intend to undertake this task here. Instead, I shall adopt a different approach to the political origins of the economic reform which interprets them as a revolt against the state and an assault on the state. From th is perspective, the central contradiction of socialist development in the classic Leninist mould is that between state and society (overlapping with, but distinguishable from, an analysis of classes and strata). The politcal impetus behind the reforms emerges from a growing tension between state and society and the increasing deleterious impact of the former on the latter.

In China, this tension took various forms in the prereform period. Ideologically, state ownership was defined as superior to other forms of production, and cooperative institutions in both industry and agriculture were pressured to aspire to this status. This atmosphere stifled non-state economic initiatives and impeded economic diversification. In all spheres, the interests of the state were given precedence over those of the collective and the individual. Politically, there was growing mass resentment against the everyday depredations of the radical Maoist principle of 'politics in command', and the stormy sea of successive political movements which beat on the heads of the population. While the Party rationalised its right to monocratic power in terms of the need for firm leadership and consistent direction, moreover, it was demonstrably unable to provide either during the Cultural Revolution decade (1966-76). Socially, there were clear tendencies for state officials to form a privileged stratum in a relatively non-commercialised system in which power counted for more than money in determining access to scarce consumption goods. Workers in state enterprises also developed into a privileged stratum within a 'dualistic' working class [Walder 1986]. Structurally, the network of party and government organisations had extended deep into the economy, more extensively than ever envisaged in the heyday of the 'Soviet Model' in the 1950s. State organs not only directly manipulated enterprises within the state sector, but also extended direct administrative controls over the nominally more autonomous collective sector. In the cities, industrial co-ops were 
amalgamated into 'big collectives' and managed as de facto state enterprises. In the countryside, state and party controls extended directly into the commune system [Gray 1985]. As a mode of economic regulation this degree of etatisation was both inefficient and ineffective. Strategically, there emerged a 'state bias' in development policies [Nolan and White 1984].

In part, this last development reflected action by the state to further what it perceived as the wider interests of society as a whole (long vs. the short term interests, the whole vs. the part). Regardless of good intentions, and even granted that state officials might be genuinely striving for a 'general interest', however, this perspective is highly problematic given the Leninist state's lack of accountability to its mass constituency and the lack of effective channels for the expression of social interests. In part, 'state bias' represented a process whereby the state increasingly came to act 'for itself', to represent apparatchik rather than worker-peasant interests. This transformation in the social nature of the state may create a link between the state and development strategy which is pathological - the interests and con tinued well-being of the state stratum became entwined with a commitment to rapid industrialisation and high levels of accumulation. This maintains or reinforces a 'statebiased' pattern of development which stresses industry over agriculture, production over exchange and services, producer over consumer goods, state over collective ownership, and which fails adequately to deliver benefits to the general population in terms of steadily rising standards of living.

Once again, there is a kind of 'Catch 22 ' operating here. A pervasive state is established in the initial stage of industrialisation for defensible reasons, but then outstays its historical welcome as a bastion of economic irrationality and political authoritarianism. The state increasingly takes on the character of a chrysalis which will not open to allow the butterfly to go free. Economic and political progress increasingly demands a transformation of the state it self and of the relationship between state and society. At the same time, the tensions generated by these contradictions in terms of productivity foregone through systematic inefficiency, sluggish income growth for the majority of the population, the apathy or antagonism created by pervasive politicisation and authoritarian control - provide the political impetus behind pressures for reform.

(ii) The political content of economic reform policies. From this point of view, the economic reforms can be seen as an assault on the state. This is reflected in the main thrusts of the programme: away from directive towards 'guidance' planning, greater autonomy for productive enterprises, expansion of market mechanisms and diversification of the structure of economic ownership. Of course, as the use of the term 'economic reform' indicates, sponsors in the CCP leadership only wish to bring about a limited readjustment of the role of the state, which will leave the framework of central planning intact and will be mainly addressed to the economic rather than political aspects of the states' role. Clearly others in China, less wedded to the status quo, would like the principle of marketisation to go much further (on the Yugoslavian model) and the economic reforms to be accompanied by equally thoroughgoing political reforms to promote democratisation.

If the state-society divide is a useful mode of explanation, it should help to analyse the differential impact of the reforms and the reaction of different groups: i.e. there should be clear differences between groups which base their social power on political, administrative or military office, or on the statist mode of production as a whole, and those whose sources of power are elsewhere and who would benefit from a change in the economic rules of the game.

Bauman's distinction between officialdom and class, as two alternative and competing power structures in socialist society provides a helpful starting point for analysing the distinction between state and society [Bauman 1974; cf. Parkin 1972 for a similar analysis]. In the Chinese context, this can be applied to distinguish those whose access to social resources depends on political and administrative authority on the one hand (officialdom) and on marketable productive skills on the other (class). The power structure based on class actually includes two hierarchies: one based on marketable skills in which the 'high intelligentsia' occupy the apex and one based on private control over economic resources including both capital and labour. In our analysis of the genesis and initial impact of the economic reforms, the latter category is not so significant, since the system of political economy operating up to 1978 prevented the rise of private economic power. As we shall see later, however, this category is very useful for analysing the longer term political effects of the reforms, particularly in the countryside.

This distinction would lead us to hypothesise that the realm of officialdom would resist the reforms and the realm of class (based on skill) would favour them. As a very general (and rather crude) framework of analysis, this seems to fit the situation. Class based elites have tended to welcome the reforms, since they promise to re-define the rules of access to social resources in their favour and to the detriment of officialdom, and to free them from the restraints previously imposed by officialdom (for example, on job mobility or use of financial resources).

To sharpen our analysis of the political implications of the state-society divide, however, we need to make several further distinctions. First, the distinction helps 
to clarify the attitudes of different groups within the state apparatus itself. The term 'state cadre' is a heterogeneous category, including political cadres (mainly party cadres), administrative cadres and 'technical cadres'. One would expect - and available evidence would support this expectation - that the last category would favour the economic reform (since it redistributes power in their favour away from the first two) even though it might undermine the power of their own institutions.

Second, one can identify a kind of 'base-superstructure' divide within the state sector of the economy, i.e. between the bureaucratic agencies of plan making and implementation on the one hand, and basic-level units of production on the other. These are distinct, and potentially conflicting, matrices of interest and power. There is a contest for control over the basic processes of economic production and social reproduction between these two spheres. To the extent that the economic reforms weaken the former and strengthen the latter, one would expect two types of reform constituency: first, enterprise managerial and technical elites $v i s-\grave{a}-v i s$ their bureaucratic supervisors and, second, within enterprises between 'representatives' of the state (Party officials or external managerial appointees) and those managers and professionals who wish to assert more unrestricted control over their own and their enterprises' activities. These distinctions do reflect political realities, but only to a limited degree since many industrial managers have become accustomed to the old system and are reluctant to change it. Moreover, the interests of different groups within the enterprise (notably the distinction between managers/professionals and manual workers) differ considerably and their reactions to the reforms follow suit.

Third, there is the distinction between the state sector and non-state sectors, i.e. between all those on the state payroll, including manual workers in state enterprises, and those in collective or private economic institutions. In the urban areas, many state manual workers have been sceptical about the reforms because they fear an erosion in the 'dualist' differential between the state and collective sectors, or are concerned about an increase in the disciplinary powers of management and the attempts to rescind the principle of job security for state workers (abolishing the so-called 'iron rice-bowl'). Conversely, many urbanities outside the state sector have benefitted from recent official encouragement of collective and (particularly) private business. In the countryside, it is clear that the main opponents of the spread of household-based 'responsibility systems' have been the cadres (at production team, production brigade and commune levels) whose previous power platforms have been dismantled. Yet, there is overwhelming evidence of grassroots peasant support for the institutional changes which abolished or loosened the state's directive planning controls over agricultural production. Indeed, the Party's acceleration of rural reforms seems to have been a response to pressure from below.

As a first-order contradiction, the divide between state and society, state and non-state economic sectors, gives us a broad picture of the pattern of support, acquiescence or resistance to the reforms. But it is clearly only a first step in more comprehensive political analysis which would have to examine other first-order contradictions (for example, based on class) and second-order factors which contribute to political diversity, such as inter-institutional conflict, ideological disagreement, regional variations and age differences. While this approach privileges the statesociety divide to explain political behaviour, it is rooted in the structural features of pre-reform etatist political economy. To the extent that, in the urbanindustrial sector, the impact of economic reform has so far been superficial, the approach retains its analytical relevance. However, to the extent that successful reforms bring about a shift in the distribution of social power and diminish the socioeconomic role of the state, they may usher in new types of politics, a prospect to which we now turn.

(iii) Political impact of the reforms. In the last issue of this Bulletin, I attempted to assess the political impact of China's economic reforms in the rural sector where the pace and degree of change has been impressive [White 1987]. My central theses were, first, that the reforms may produce an institutional vacuum in the countryside which cannot accommodate the accompanying process of socio-economic diversification; and second, that they carry the potential for creating alternative centres of market power, based on private control over economic resources, which may change the basic nature of rural politics and lead to tension with the state institutions which remain in place. The rise of new political forces and issues requires a new framework of political institutions to regulate interaction, absorb pressures and contain conflict. This will very probably require greater scope for the activity of new socio-economic organisations, with a degree of independence from the state, which represent the rapidly differentiating constellation of rural interests (notably new forms of marketing and producer associations).

One can also make a case that a process of gradual political democratisation, either direct or representative, at the village rural and township level is advisable to act as a check on emerging local elites, whether party/government officials, or a new rural bourgeoisie or rich peasant stratum, and to provide a framework for managing and containing the more complex processes of local politics which the reforms appear to be ushering into the Chinese countryside. 
In the heartland of the state economy, the urbanindustrial sector, the pace of reforms has been far more uneven and slow and the degree of significant change far less. The CCP leadership appears committed to the deepening of the reform process, however, and, to the extent that they are successful, a significant decentralisation and diversification of economic power will take place, as in the rural sector, in this case flowing from the transfer of decisionmaking power from Party or state officials to the managers of enterprises. Enterprise managers, in both public and non-public sectors, will wish to organise and assert their power in relation to the political and administrative authorities. Early signs of this process are already visible: in organisational terms the establishment of intermediate institutions such as trade associations of state, collective or private firms which are acting as mediating bodies between individual firms and the regulatory authorities; in social terms, the emergence of a new stratum of 'entrepreneurs' (or in the Chinese translation 'enterprisers', qiyejia) i.e. enterprise managers who are developing an esprit de corps distinct from both state officials on the one side and their workforces on the other.

Therefore, in the urban industrial as in the rural sector, one can expect the evolution of a more complex and decentralised political process over economic issues, with new institutional and group actors. This will bring two major changes in the Chinese political process: first, relations between enterprises and their representatives on the one hand, and the party-state apparatus on the other, will be based more on bargaining and compromise than previously; second, the Party itself will need to change its role, away from a traditional conception of leadership based on hierarchical subordination and politico-ideological mobilisation to one which can accommodate to and mediate between competing economic interests. One end-point to this emerging process of political change might well be some form of 'socialist pluralism' along corporatist lines.

\section{Conclusion: Prospects for Democratisation}

One could regard the emergence of this kind of corporatist pluralism as one expression of political liberalisation or democratisation, but one should not then leap to the conclusion that successful economic liberalisation will bring in sweeping political democratisation. The Yugoslavian case, where expansion of the market has not been accompanied by significant political reform, would suggest the contrary, as would those Third World capitalist contexts (such as Chile) where economic liberalism has been symbiotic with political authoritarianism. Indeed the CCP leadership would argue that the maintenance of strong authoritarian controls are necessary because of the need to manage the economic reform.

Democratisation worth the name would embody certain central features other than the corporate pluralism' identified above as the most likely political outcome of the economic reforms. Three are particularly important: (i) the protection of the political rights of individuals in relation to the group, organisation, collective or state by an effective and autonomous legal system, by institutionalised checks on bureaucratic or political injustice (for example, through special appeal and arbitration procedures, or independent ombudsmen) and by mechanisms to ensure the accountability of public officials; (ii) an increase in the political rights of the population as citizens, i.e. their ability to influence the direction of social development and the content of planning through electoral processes and representative institutions; (iii) the rights of individuals or groups as producers or 'citizens of the workplace' and their extension through forms of worker control and self-management.

The impact of the economic reforms on these dimensions of democratisation is likely to be ambiguous. On the positive side, the evident need for a more comprehensive framework of economic law to regulate the proposed 'socialist commodity economy' may strengthen the role of law generally and extend its protection beyond the economic sphere. On the negative side, however, the attempt to rationalise industrial relations through the adoption of Western management techniques flies directly in the face of any attempt to establish worker self-management in Chinese enterprises; nor is there any evidence of an organic link between economic decentralisation and the growth of representative political institutions.

It is true that the post-Mao period of economic reform has brought some limited improvements in Chinese political life. The range of economic, intellectual and cultural freedom has expanded considerably, and the intrusion of the state into the private sphere has declined. Within the Party, there is greater scope for debate and disagreement; outside the Party there have been limited steps towards democratisation. In 1979, for example, the principle of direct elections was extended to county-level People's Congresses; in enterprises, the role of 'workers representative congresses' has been increased to give workers a limited say in management decisions. But these have a marginal impact on the overall distribution of power which is still set in the Leninist mould; nor do they go very far in increasing the accountability of public officials

Many Chinese, including a new breed of political scientist, would argue that further democratisation is necessary in all the senses identified above. Apart from the proposition that a distinctively socialist transition is unthinkable without it, they would argue that it is 
also developmentally essential. China has passed that phase when the argument that democracy must be subordinated to the priorities of industrialisation still carried weight, and has already entered a new stage when democratisation must be seen as a precondition for further social and economic advance. However, the obstacles to democratisation are still severe. China is still a poor country, where the struggle for everyday life limits the capacity of citizens to devote significant time and energy to political activity. The dead hand of traditional authoritarian political culture still grips hard; and conservative vested interests in the Partystate apparatus are still powerful.

To the extent that these demands for democratisation gain force the Party faces some difficult choices. Even if it retains its monopoly position, it must accept a considerable diminution of its ability to control events. It is clear that genuine democratisation will require a major change in the role of the 'vanguard' Party. Historical experience suggests that, whereas in the earliest phases of socialist transition, the Party is seen as the solution, in later stages, it becomes the problem. This problem reflects deep contradictions at the root of the politics of state socialism which still await resolution.

\section{References}

Bauman, Z., 1974, 'Officialdom and class: bases of inequality in socialist society", in Frank Parkin (ed.). The Social Analy'sis of Class Structure, London, Tavistock, pp 129-48

Gray, Jack, 1985, 'The state and the rural economy in the Chinese People's Republic', in G. White and R. Wade (eds.), op. cit.

-and Gordon White (eds.), 1982, China's New Development Strategr, Academic Press, London

Nolan, Peter and Gordon White, 1984, "Urban bias, rural bias or state bias? Urban-rural relations in postrevolutionary China', Journal of Development Studies, vol 20 no 3, April, pp 52-81

Parkin, Frank, 1972, 'System contradiction and political transformation', Archives Européennes de sociologie, vol XIII no 1, pp 45-62

Walder, A. G., 1986, Communist Neo-Traditionalism: Work and Authority in Chinese Industry, University of California Press, London

White, Gordon, 1987, 'Political aspects of rural economic reform in China", IDS Bulletin vol 18 no 3, July

-and Robert Wade, 1985, 'Developmental States in East Asia', Research Report 16, IDS, Sussex 